\title{
Article \\ Intermediate Conditions of Democratic Accountability: A Response to Electoral Skepticism
}

\author{
J. S. Maloy \\ Department of Political Science, University of Louisiana at Lafayette, Lafayette, LA 70504, USA; \\ E-Mail: maloy@louisiana.edu
}

Submitted: 2 February 2015 | In Revised Form: 14 July 2015 | Accepted: 17 July 2015|

Published: 28 August 2015

\begin{abstract}
Attempts to respond to "democratic deficits" in modern constitutional republics must contend with the broad scholarly trend of electoral skepticism. While generally casting doubt on periodic competitive elections' suitability as vehicles of accountability, electoral skepticism does not necessarily entail an absolute devaluation of elections. Some normative and empirical research responds to this trend by refocusing attention on values other than popular power, such as civil peace, which might be served by periodic competitive elections. Another response short of abandoning the value of popular power, however, is to draw out possibilities for institutional design from the restricted conditions under which previous study has found electoral accountability to be plausible or likely. This second task requires an empirically informed exercise in political theory. Pursuing it in a programmatic and policy-relevant way requires descending from the grand, systemic level of constitutional structures and electoral formulae to intermediate (or middle-range) institutional conditions of accountability, such as rules about parties, campaigns, and election administration. My analysis reinterprets principal-agent models to develop four general types of crucial condition for electoral accountability, and then ramifies this scheme by reference to recent empirical research. The result is a "top ten" list of specific institutional factors that could be theoretically decisive in helping or hindering electoral accountability. These ten conditions could guide future research designs and reform proposals alike.
\end{abstract}

\section{Keywords}

accountability; democratic theory; democratic representation; electoral studies; institutional reform

Issue

This article is part of a regular issue of Politics and Governance, edited by Professor Andrej J. Zwitter (University of Groningen, The Netherlands) and Professor Amelia Hadfield (Canterbury Christ Church University, UK).

(C) 2015 by the author; licensee Cogitatio (Lisbon, Portugal). This article is licensed under a Creative Commons Attribution 4.0 International License (CC BY).

\section{Introduction}

The cumulative effect of empirical research over time is often to modify or to qualify the conventional wisdom on a given topic. This has arguably been the case with research on elections and democratic accountability. Tremendous rhetorical and ideological leverage has been gained for generations, and for centuries in some parts of the globe (Maloy, 2008), through the notion that periodic competitive elections allow ordinary people to sanction or otherwise to control policy-making elites. But the "third wave" of democratization in the 1990's triggered intensified scrutiny of this proposition, both theoretically and empirically (see Przeworski, Stokes, \& Manin, 1999), and the resulting scholarly inquest has led to significant (though not absolute) levels of what might be termed "electoral skepticism". As a result, the relation between competitive elections and democratic accountability is now widely understood to be problematic and delicate rather than natural and robust (see Anderson, 2007; Maloy, 2014).

Three types of normative and programmatic response to electoral skepticism present interesting options for the future of democratic institutions. One is to 
continue to defend periodic competitive elections in more or less the forms they take in the wealthier and older democracies, but to do so on modified grounds. There are other political values besides popular power, after all, and "minimalist" theories of democracy (e.g. Przeworski, 1999) have plausibly identified several candidates, notably civil peace, as resulting from a modicum of electoral competition among political elites. Empirical studies of "losers' consent" (see Anderson, Blais, Bowler, Donovan, \& Listhaug, 2005) can be understood as contributing to this normative project of justifying electoral democracy in chastened terms. A second kind of response to electoral skepticism is to pursue democratic accountability through non-electoral devices such as random selection, applied to new kinds of legislative process (e.g. Callenbach \& Phillips, 2008; Leib, 2004; McCormick, 2011; Sutherland, 2008; Zakaras, 2010). A third response is to pursue further investigation of the precise conditions under which democratic accountability could plausibly result from periodic elections. Since the most direct route to the possibility of deliberate change lies in formal rules and procedures, deepening our knowledge of specifically institutional factors of electoral accountability might support practical reform proposals for institutional design.

This article is an attempt to assay the last of these options by systematically charting, in conceptual terms, the intermediate institutional conditions of electoral accountability. There is a well established literature in political science on the effects of institutional variation on electoral outcomes which could inform such an effort, but these studies tend to focus on the grand, systemic level of constitutional structures or electoral systems (e.g. Carey, 2009; Hellwig \& Samuels, 2008; Powell, 2000)-where only major political upheaval could lead to change. What is still needed, if we are to make a fair assessment of the institutional possibilities of electoral accountability, is a theoretic framework for intermediate conditions, in the middle range of institutionalization where the design and interpretation of empirical studies could interface in a constructive and coherent fashion with normative and programmatic proposals. My purpose, then, is to lay a conceptual foundation for future studies of and efforts toward electoral redesign. Instead of testing empirical hypotheses, I am attempting to survey the field of theoretic possibilities and to provide a road-map for designing empirical studies to explore those possibilities further.

The analysis below identifies the general value of popular power as the normative stakes in investigating the strength or weakness of electoral accountability (in Section 2) and then offers an exercise in empirically informed political theory to identify potential institutional responses. I reinterpret previous theoretic work in principal-agent theory (in Section 3), emphasizing the skeptical drift of that tradition, and derive from it four "crucial conditions" of electoral accountability (in Section 4). I then engage empirical work on elections to identify, within these four general categories, ten specific "spoiler conditions" that militate against accountability and provide ammunition for electoral skepticism (in Section 5). At the same time, however, this "top ten" list supplies a basis for developing intermediate institutional conditions that could counter the spoiler conditions and thereby promote greater accountability through elections.

\section{Conceptual Contours of Electoral Accountability}

Empirical scholars of elections have long recognized that their factual findings are implicated in core concepts and propositions of democratic theory. Perhaps the most basic principle involved is popular power: periodic competitive elections have often been valued for their presumed ability to enable ordinary citizens to exercise control over their lives, or at least over the public policies that shape, structure, or otherwise affect their lives. Yet "power" is a general term that can encompass a wide variety of forms and degrees, as illustrated by the crucial dichotomy of "control" and "influence" (Key, 1966). Whether and when citizens can exercise directed, purposeful control over public policy, as opposed to effective yet diffuse influence, is therefore a key question for analytic and normative theory alike.

Because conventional assumptions about electoral accountability hold that elections enable voters to sanction governments, it is important to recognize that the power of sanction might in theory lead to control, or to influence, or to something in between. My analysis does not take a position on this spectrum, either analytically (is it possible for elections to effect one or the other type of popular power?) or normatively (would it be good if elections could effect one or the other type of popular power?), but is addressing the debate in a fundamental way nonetheless. I am trying to show that this debate is still relevant and consequential, rather than purely academic-against the notion that the value of popular power via elections should be discarded as practically futile, in favor of other values. What I offer below, then, is not a normative analysis of which values elections ought and ought not to serve, but rather a conceptual analysis of what sorts of institutional conditions can and cannot serve the general principle of popular power. As I proceed, I will use "power" loosely, sometimes as control and other times as influence: the intermediate-conditions framework contributed by this article can provide an essential bridge between theory and empirics for projects of institutional design which are geared toward either type of power.

Since elections (unlike initiatives and referenda) offer candidates and parties rather than policies as the objects of citizens' choice, popular power over policy is mediated by the electoral sanction wielded by voters 
over those candidates and parties. For this reason, principal-agent theory provides a useful analytic starting-point for studying elections as vehicles of institutionalized popular power.

Two issues must be distinguished when thinking of elections as mediating the relationship between voters as principals and politicians as agents. (The conceptual framework set up in this paragraph, and employed throughout, is abbreviated and adapted from Maloy, 2014, pp. 14-15.) First and foremost is the question of how far the agents implement the principals' will or serve their interest. (The distinction between will and interest is important, analytically and normatively, but does not affect the basic conceptual framework.) This is the question of responsiveness, strictly speaking. But a second, distinct question is also important: what mechanisms are supposed to enforce responsiveness? This is the question of accountability, strictly speaking, since elections are supposed to give voters an effective sanction that will bear some causal value toward responsiveness by deterring politicians from being unfaithful. Responsiveness and accountability are therefore best considered as two aspects of the broader phenomenon of democratic representation, and in principle they may vary independently of one another, depending on circumstances (i.e. responsive government may vary for reasons unrelated to electoral sanctions, and vice versa). This distinction is also important because a plausible line of thought holds that the weight of democratic value really lies mostly with responsiveness, relegating accountability to a contingent means to that end, so that skepticism about accountability (though justified in itself) should not trouble us much but should merely refocus our attention on responsiveness (Anderson, 2007, pp. 289-290). In short, I am attempting to pre-empt this line of thought by reexamining the capacity of electoral institutions to deliver effective sanctions into the hands of voters.

When we think about the significance of institutional variation for conditions of electoral accountability, previous empirical literatures provide some guidance at the grand, systemic level of constitutional structures (i.e. presidential vs. parliamentary systems) and electoral formulae (i.e. proportional vs. majoritarian systems). These insights have practical application in relatively rare cases of major upheaval, when the most basic constitutional structures may be changed in deliberate fashion, as in Afghanistan, Iraq, Tunisia, and Egypt in the past decade or so. Richer, more established democracies may also have opportunities to change institutions at the systemic level, on occasion. But practical reform efforts are more likely at the middle range of institutional design, through majoritarian processes of ordinary legislation rather than supermajoritarian processes of constitutional amendmentor indeed extralegal processes, as in the four cases mentioned above.
The search for intermediate conditions of accountability should begin with general analytic principles about which characteristics would be theoretically decisive for elections' capacity to endow voters with effective sanctioning powers. Principal-agent theory, albeit reinterpreted somewhat, provides useful prompts toward this end (in Section 3), leading to four general types of accountability condition (in Section 4). Empirical research on elections can then be engaged to direct the analysis toward more specific conditions in the middle range of institutionalized accountability (in Section 5).

\section{Principal-Agent Models and Their Limitations}

Principal-agent theory has succeeded in isolating electoral accountability as a problem for investigation in fairly precise terms and has inspired some empirical testing over the years. More to the point, for my purposes, are the limitations that it has identified in elections' capacity to serve as vehicles of popular power. Principal-agent theory's efforts in specifying necessary conditions that must obtain in order for electoral accountability to be analytically plausible are in fact compatible with a robust skepticism about electoral accountability in the real world.

Barro (1973) is often credited with having planted the seeds for the principal-agent approach to elections, and his legacy is best understood as including significant limitations on the possibility of accountability. He kept his theoretic model simple by assuming the existence of three empirical conditions: (a) the presence of competitive elections (Barro, 1973, p. 19), (b) the absence of incumbents' control over the electoral process itself (p. 26), and (c) the absence of political parties ( $p$. 41). These admittedly unrealistic conditions were necessary for what Barro called "electoral control," with the clear implication that such control would be attenuated in actual contexts where the necessary conditions were not present.

Ferejohn (1986) noticed two other implicit but crucial assumptions of Barro's analysis: (d) symmetric information and (e) unitary evaluative standards. Finding these conditions also to be unrealistic, he replaced them with asymmetric information as between voters and incumbents and diversity of normative criteria among voters themselves (Ferejohn, 1986, p. 10). Ferejohn's conclusion was that modifying Barro's fourth and fifth assumptions in this way would allow incumbents to exploit their superior information by masking their real failings and "to play off the voters against one another" in order to maximize chances of reelection (see also Ferejohn, 1999, pp. 132-134). This analysis represented a significant gain in realism by introducing political manipulation as a factor. The result, in Ferejohn's words, "vastly reduc[ed] the level of electoral control" even compared to Barro's already modest expectations-unless, that is, citizens could under- 
take "sociotropic" voting by abandoning their selfregarding motives in favor of some unitary criterion of public welfare (Ferejohn, 1986, pp. 20-22). In effect, Ferejohn managed to make Barro's assumption about informational symmetry to seem less problematic while still getting stuck at the assumption about unitary evaluative standards. As the rational-choice model of electoral accountability became more realistic in its assumptions, expected levels of popular power got weaker.

More recent theoretic work on principal-agent models of electoral accountability has struggled to paint any brighter a picture, despite the occasional glimmer of light. On the one hand, some theorists suggest that two new assumptions about the necessary conditions for electoral accountability can realistically be satisfied. To summarize, Barro's five original assumptions were symmetric information, unitary evaluative standards, the absence of political parties, competitive elections, and independent electoral structures (i.e. immune to manipulation by incumbents). Recent studies have modified the first, informational assumption by focussing on the quality of voters' information, rather than symmetry, and have made explicit a sixth assumption to the effect that politicians must feel incentivized to gain and retain office (see Ashworth, 2012). Others have suggested that the problem of corruption or shirking by agents can be reasoned away within this sort of framework. To the extent that "agents have an interest in making themselves accountable in order to get the principal to trust them with more resources," politicians should be expected to institute self-imposed constraints like direct primaries and campaign-finance regulations (Ferejohn, 1999, pp. 138-141, 148-150). Some of Barro's assumptions about necessary conditions, it seems, could be satisfied or relaxed.

On the other hand, the overall picture still seems cloudy, and a strong (though not total) form of skepticism has been built on the basis of considerations generally familiar from the early rational-choice efforts. Above all is voters' poor information, undoubtedly the leading theme of the most insightful studies (Besley, 2006, pp. 37-43; Ferejohn, 1999, p. 132; Manin, Przeworski, \& Stokes, 1999, pp. 41-42; Maravall, 1999, pp. 159-161). A related problem is that complex policy issues make it difficult for voters to assign "responsibilities for outcomes" (Besley, 2006, p. 105; Dunn, 1999, p. 337), as do complex institutional structures of decision-making (Manin et al., 1999, p. 47). Voters' own pluralistic preferences and the diverse characters of politicians offer opportunities for manipulative and evasive behavior by the latter (Besley, 2006, pp. 106107, 124; Ferejohn, 1999, p. 132). In numerous ways, political parties may make such behavior more rather than less likely (Maravall, 1999, pp. 166-167, 192). Finally, the absence of a competitive environment for politics would be fatal (Besley, 2006, pp. 124-128), and various other characteristics of the institutional environment surrounding elections may inhibit accountability. For instance, rules about campaign funding may skew representatives' incentives toward heeding prominent donors at the expense of the broader public (Manin et al., 1999, pp. 34-35).

In summary, the frequent appeal to non-electoral mechanisms like watchdog and judicial agencies in more recent research on accountability (Besley, 2006, p. 225; Manin et al., 1999, pp. 50-51; O’Donnell, 2003) has been predicated on the tacit or explicit admission that elections are incapable of doing the job on their own. The most thorough of recent explorations of the principal-agent perspective on electoral accountability concludes, in conspicuously diplomatic fashion, that "it is less than clear whether the weight attached to the importance of elections in modern representative democracies would emerge from this approach" (Besley, 2006, p. 99). More bluntly, democratic elections are "highly imperfect" and possess "incomplete ability to discipline and select incumbents" (p. 196). This is more or less the early conclusion drawn by Barro and Ferejohn, but now with a great deal more empirical study and theoretical reflection behind it.

It is interesting to note that this "C-minus" kind of electoral skepticism, suggesting that elections are not a complete failure but do suffer from major deficits of accountability, is based on more or less the same limiting conditions that emerged from early theoretic efforts. We can sum them up under four headings: starting with Barro's five assumptions (three explicit, two implicit), we may add a sixth about politicians' incentives; we may then subtract the two assumptions about parties and electoral rules by bundling them together with the assumption about institutions. (Two conditions that define periodic competitive elections, as the phenomenon under analysis, are assumed throughout rather than enumerated: elections are held at stated intervals and always feature more than one genuine contender.)

\section{Crucial Conditions of Electoral Accountability}

A. Information. Voters must have good information to use in deciding how far to reward or punish politicians for actual governmental conduct. Given access to accurate and unbiased information, voters must be able to form realistic judgments about the empirical properties of politicians and policies if the threat of electoral sanction is to be fully credible. This type of condition involves both media (as a social structure) and psychology or cognition (as an individual trait); our focus will be on institutional structures relating to public discourse.

$B$. Incentives. Politicians must feel induced by potential rewards and deterred by potential punishments if they are to engage in the sort of anticipatory behavior that could be taken as evidence of effective sanc- 
tions. Their attitudes toward office-holding must be sufficiently risk-averse, and the perquisites of office sufficiently appealing, to make them care about their electoral fate in advance of voters' verdicts. In addition to elite culture on topics like honor and shame, formal rules about tenure are relevant here; our focus will be on institutional structures relating to compensation and corruption.

C. Procedures. Certain basic rules of the electoral game must be in place and must be arranged independently of the politicians whose fates are stake. Crucially, electoral contests must include genuine alternatives for voters (hence the importance of political parties), and other features of the electoral process (e.g. districting and funding) must not be rigged for incumbents' structural advantage. Elite attitudes about gaming the system may be relevant here, but this condition is primarily about formal rules and procedures relating to parties and campaigns.

$D$. Norms. Voters must be able to co-ordinate their judgments in order to make the voting process capable of delivering an effective sanction with a coherent purpose. In the absence of shared norms about which criteria should determine whether governmental actors and actions get rewarded or punished, politicians' use of targeted appeals on different topics for different voters may lead to sanctions unrelated to their performance in major policy areas. Cultural, psychological, and behavioral variables are obviously preponderant here, but institutional structures relating to electoral administration and vote-counting may also affect voters' ability to deliver coherent verdicts through the ballot box.

These crucial conditions describe general factors that obviously interact with one another in the real world to contribute toward electoral outcomes-a key consideration for the design of empirical studies that pursue precise causal relations and mechanisms. Each condition by itself implicates different types of variables, including both cultural and structural ones. I now develop a "top ten" list of more specific spoiler conditions, or types of variance which have empirically been found to diminish or vitiate electoral accountability. This list provides a capsule or overview of the empirical case for electoral skepticism. At the same time, however, and consistent with the structural focus of my analysis, it can organize our thinking about specific institutional variables whose effects on the capacity of periodic competitive elections to endow voters with effective sanctioning power would make them central to normative and programmatic efforts. However discouraging the diagnosis may appear, the prescription for a cure depends on it.

\section{Spoiler Conditions of Electoral Accountability}

Two benefits may arise from considering evidence about specific circumstances under which the four cru- cial conditions of electoral accountability are negatively impacted. For the design of democratic institutions, we need guidance about what sorts of rules and procedures may help or hinder the efficacy of elections as vehicles of popular power. For the design of empirical studies, whoever aspires to tell plausible causal stories about electoral accountability must pay heed to the contexts (of information, incentives, procedures, and norms) in which the electoral data subject to analysis and interpretation have been generated.

The list of spoiler conditions below tracks the four crucial conditions ( $A$ through $D$ ) but elaborates on each one, resulting in more specific factors (1 through 10). For each spoiler condition, I offer remarks on not only the state of empirical knowledge and methodological practice but also theoretical and institutional ramifications. (Crucial conditions, spoiler conditions, and institutional remedies are summarized in Table 1.)

Table 1. Summary of analysis.

\begin{tabular}{|c|c|c|}
\hline $\begin{array}{l}\text { Crucial } \\
\text { conditions }\end{array}$ & Spoiler conditions & $\begin{array}{l}\text { Intermediate } \\
\text { remedies }\end{array}$ \\
\hline \multirow[t]{3}{*}{ A. Information } & 1. Poor information & Publicly owned media \\
\hline & 2. Poor judgment & $\begin{array}{l}\text { Deliberative } \\
\text { assemblies }\end{array}$ \\
\hline & $\begin{array}{l}\text { 3. Misattributed } \\
\text { responsibility }\end{array}$ & Clarity of jurisdiction \\
\hline \multirow[t]{2}{*}{ B. Incentives } & 4. Misincentives & $\begin{array}{l}\text { Adequate } \\
\text { compensation }\end{array}$ \\
\hline & $\begin{array}{l}\text { 5. Pecuniary } \\
\text { corruption }\end{array}$ & Judicial monitoring \\
\hline \multirow[t]{3}{*}{ C. Procedures } & $\begin{array}{l}\text { 6. Unequal campaign } \\
\text { funding }\end{array}$ & $\begin{array}{l}\text { Public financing, free } \\
\text { media }\end{array}$ \\
\hline & 7. Weak parties & $\begin{array}{l}\text { Internal party } \\
\text { discipline }\end{array}$ \\
\hline & 8. Strong parties & $\begin{array}{l}\text { Non-partisan } \\
\text { districting, open } \\
\text { primaries }\end{array}$ \\
\hline \multirow[t]{2}{*}{ D. Norms } & 9. Electoral fraud & Election monitoring \\
\hline & $\begin{array}{l}\text { 10. Electoral } \\
\text { inaccuracy }\end{array}$ & $\begin{array}{l}\text { Recountable } \\
\text { technology }\end{array}$ \\
\hline
\end{tabular}

\section{A-1. Poor Information}

The empirical reality of widespread voter ignorance about public affairs, even in relatively affluent and educated societies (Hardin, 2000), is perhaps the most obvious deficit of accountability in actual electoral processes. One aspect of the information problem comes from the supply side, the news media. For example, we know from studies of the USA that there are significant inequalities between residents of "rich" and "poor" media environments (Arnold, 2004, pp. 251-253), and that poor media environments tend to be represented by less responsive politicians (Snyder \& Stromberg, 2010). We also know that voters in Italy (Chang, Golden, \& Hill, 2010) and the USA (Berry \& Howell, 2007) have been able to reward or punish incumbents for 
performance when media gives intensive scrutiny to relevant issues, but not otherwise. Failures of journalistic institutions, then, translate into failures of electoral accountability.

An important methodological lesson immediately follows from the reality of generally poor information: opinion data from opt-in surveys (e.g. Jones, 2011) should be treated with caution when interpreting the results of quantitative analysis because they tend to bias the sample toward better informed members of the electorate.

Electronic media have been altering the traditional print and broadcast landscape, of course. It is as yet unclear whether new media and channels of information will reach as broad an audience (Snyder \& Stromberg, 2010, pp. 403-404) or will provide the same level of investigative reporting (Chang et al., 2010, p. 216) as traditional print media used to do. In short, how far is the "wired" citizen a well informed citizen? Some research suggests that, because the World Wide Web makes it easier for consumers of news to access exclusively partisan sources, "the share of politically uninformed people [in the USA] has risen since we entered the so-called information age" (Prior, 2007, p. 134). It will be crucial to determine whether this finding, suitably updated for the Twitter and smart-phone era, extends beyond American shores-and, if not, for what reason.

Programmatically, opportunities for research and reform lie in exploring differences across regimes of public law as to news and communications. It is widely accepted, of course, that press freedom is a necessary condition of empowering ordinary citizens with good information about their government; but it is not a sufficient condition. In short, media law matters - and may be altered more readily than constitutional provisions related to free speech. Some relevant crosscountry variations include public vs. private ownership of media and variations in editorial control or censorship by vested interests (governmental or otherwise). Theoretically, public ownership tends to remove commercial considerations from the dissemination of political news, resulting in greater accuracy and relevance of political information. At the same time, governmental control of content poses a threat to accuracy and relevance. A crucial question, then, concerns how far a news-provider's public financing is in fact consistent with its operational autonomy from the state, and how far striking this balance legally and institutionally can make a difference in the information that voters take to the polls.

\section{A-2. Poor Judgment}

The electoral effects of information involve consumers as well as producers, and various kinds of cognitive error and bias among voters may endanger the electoral connection. Even when the flow of relevant information is at high tide, intensive exposure to major policy issues may have the effect of exacerbating voters' partisan misperceptions and rationalizations (Claassen \& Highton, 2006; Wolpert \& Gimpel, 1997). Research on American politics has shown that misperceptions may result from choosing a narrow range of media sources even when alternatives are available (Kull, Ramsay, \& Lewis, 2004). Difficulty of recall leads voters to weight recent information much more heavily than information about earlier periods of a representative's term (Huber, Hill, \& Lenz, 2012), which may explain why politicians often wait until just prior to election day to engage in deviant behavior resembling responsiveness (Jacobs \& Shapiro, 2000, pp. 43-44). In a broader, comparative context, we know that accurate information often passes through partisan or ideological filters before voters use it in their electoral choices (Anderson, 2007, pp. 279-281), and that many voters cling to relatively immovable electoral preferences and contort political information into rationalizations of those preferences (Maravall, 2010, pp. 91-92).

In short, even a plentiful supply of political news through the media could not guarantee that voters would use information in a calculated and instrumental fashion on election day. Given the normative assumption that rewards and punishments (in any sphere of action) are better dispensed in a calculated rather than impulsive way, this is a troubling reality for principalagent models and, more broadly, for the prospects of elections as vehicles of popular power. The tempting response is to abandon all hope for electoral accountability, or else to embrace it only in the context of a constricted, "opt-in" democracy of deliberative citizens (which may flout normative standards of descriptive representation).

Two important caveats, however, may temper this kind of response. First, some empirical evidence from the USA suggests that exposure to policy-related information can in fact override elite partisan cues among a significant number of citizens, even partisan ones (Bullock, 2011). In short, perhaps we simply need to see better provision of information (the problem addressed above) in order to see citizens using what they have more carefully.

Second, and more theoretically, if citizens' behavior with respect to political information results from their sense of efficacy, which in turn is a function of existing electoral institutions, then some kinds of electoral reform may alter the future behavior of voters. In short, those who currently appear hopelessly misinformed may only be contingently misinformed, thanks in part to electoral structures that currently supply weak incentives for becoming informed. Instead of relying on institutions of public education to solve general problems of information and judgment, proposals for learning by doing may be predicated on the notion that cer- 
tain kinds of political institutions themselves already educate (or miseducate) citizens in the habits and skills of democratic citizenship. For example, jury service in the USA has been shown to increase voting participation (Gastil, Deess, Weiser, \& Simmons, 2010). In a similar vein, though more focussed on the problem of information, perhaps theories of "deliberative democracy" are most usefully understood as visionary proposals to turn focus groups, constituent juries, deliberative assemblies, and "Deliberation Day" activities into new schools of citizenship. Even if these new schools are no more effective than the old (public) schools, the educative effect of institutions is a useful theoretic premise for researchers and reformers to bear in mind when considering voter information and judgment.

\section{A-3. Misattributed Responsibility}

A particularly important aspect of political information which is relevant to electoral behavior involves the question of who is responsible for what. This is an area in which partisan and ideological rationalizations enjoy particularly broad scope for playing havoc with voters' judgments. A high level of complexity in not only the policy issues themselves but also the institutions that make policy can contribute to muddled attributions of responsibility. The concept of "clarity of responsibility" was devised to measure the institutional properties of this dynamic in the analysis of economic voting in European states (Powell \& Whitten, 1993), and a whole host of related studies have followed. Voters in Latin America have been found to blame incumbents at subnational levels of government for the effects of national policies, and vice versa (Gelineau \& Remmer, 2005). In a similar vein, the split authorities of "divided federalism" in the USA lead many voters to attribute responsibility for economic conditions to state governors or national presidents based on partisan bias more than political or economic reality (Brown, 2010). Another study of Latin American voters has found that they tend to blame international agencies rather than domestic governments for the effects of domestic economic policy (Alcaniz \& Hellwig, 2011).

Theoretically, the rule of thumb is that simpler and less obscured institutional structures for policy-making correspond to fewer "veto players" (Tsebelis, 2002) or "vetogates" (Eskridge, 2008). Among other considerations, multiple veto players make a policy process resemble a negotiation, with voters in the position of outside observers. In any type of negotiation, usually only the negotiators themselves know how to allot responsibility for the outcome-and even there they may disagree, to say nothing of the outside observers. The political handling of the Greek financial crisis within the European Union in the last few years nicely illustrates one sort of problem with clarity of responsibility in a complex negotiation.
Programmatically, obscured responsibility is one of the most intractable spoiler conditions because it implicates some of the most entrenched features of a political regime: presidential vs. parliamentary executives, unicameral vs. multicameral legislatures, and varieties of party system. Intermediate institutional reforms may yet have some impact, however. The key theoretic consideration here is that clarity of responsibility (as an operational factor in voters' minds) can be promoted by clarity of jurisdiction (as an institutional or structural factor in public law). Ordinary legislation can in theory promote clarity of jurisdiction by rendering the scope of authoritative decisions readily traceable to identifiable agents.

Assistance here is supplied by research that has expanded on the original "horizontal" emphasis of clarity of responsibility (i.e. among parties, legislatures, and executives, at the national or central level of government) by investigating "vertical" jurisdictional relations (i.e. between local and central authorities). A crossnational analysis has found, for example, that the existence of a federal structure does not pose as great a problem for clarity of responsibility for economic policy as does the substantive devolution of fiscal powers to regional authorities (Anderson, 2006). A unitary system with decentralized fiscal powers does more to obscure economic reponsibility than a federal system with centralized fiscal powers. A more fine-grained analysis of regional governments in Spain has found that voters only struggle to hold the appropriate authorities responsible when their regional governments share evenly balanced powers with the central state, but not when regional governments have either high or low levels of autonomy vis-a-vis the national regime (Leon, 2011). The recipe for empowering voters, consistent with the structural precept of clarity of jurisdiction, requires choosing either very much or very little decentralization. More generally, reformers might consider the message of Thomas Paine (himself a supporter of a federal political system, ca. 1776): democracy is favored by institutional simplicity and retarded by institutional complexity (Paine, 2003, pp. 7-9, 248-251, 294-301).

\section{B-4. Misincentives}

Electoral accountability depends on the motivation of incumbents to retain their seats on election day, but politicians' incentives for actually retaining office are sometimes too weak to give voters the power of deterrent control. In local governments in rural China, for example, official salaries are meager and elected officers therefore little fearful of the consequences of disappointing their constituents' expectations (Tsai, 2007, pp. 254-255). In other countries, the problem does not take this form: United States senators' and representatives' salaries exceed the median citizen's earnings by a 
factor of four or five. But non-monetary aspects of elected office can also corrode the motivation to win re-election. The potential gains of unrepresentative behavior may over-balance the potential costs of poor electoral performance. As a study of Brazilian mayors has shown, people who become career politicians do not necessarily have risk-averse personalities (Pereira, Melo, \& Figueiredo, 2009).

Methodologically, therefore, a decision not to face the voters again at the next poll cannot always be construed (e.g. Cox \& Katz, 2002) as an evasion of likely defeat by a risk-averse incumbent; the deterrent effect depends heavily on context.

Programmatically, regimes of election law that aspire to promote accountability must be tailored to provide a solid structure of incentives for elected officers. Importantly, these incentives involve not only the local standard of living but also cultural variables like honor and shame. One danger of raising material rewards like salaries is that elected officers may be thereby set off as a privileged class, psychically separated from the citizens they are supposed to serve (Bachner \& Ginsburg, 2014). Exploiting moral rewards would be more likely, in theory, to have the opposite effect, binding voters and politicians together as members of a single citizen body. The availability of such rewards, of course, is likely to vary a great deal across countries and cultures, making their activation through intermediate institutions like audits and ombudsmen plausible in some contexts but not others.

\section{B-5. Pecuniary Corruption}

Even healthy levels of official compensation might be overwhelmed by monetary inducements from unofficial sources. In theory, modern democracies respect the rule of "one person, one vote," but none of them enforces a similarly egalitarian distribution of economic resources. An extreme example can serve to illustrate the general problem of representatives' incentives in conditions of inequality: the Peruvian state in the 1990 's played host to an elaborate scheme of bribery, operated on behalf of the elected president by his intelligence chief (McMillan \& Zoido, 2004). The monthly cost of a non-partisan judge in Peru was about $\$ 10,000$; of a deputy from another party, $\$ 20,000$; of the owner of a private television network, $\$ 60,000$. This scheme gave members of the opposition ample incentives not to be responsive to their supporters.

Theoretically, pecuniary corruption fundamentally severs the causal chain of accountability by skewing the incentives that could in principle give deterrent power to the prospect of electoral defeat. Moreover, whereas kick-backs and bribes may diminish a representative's material incentive to be re-elected at all, the stable presence of the sources of corruption would tend to lower the probability that victorious challeng- ers would govern differently from defeated incumbents. Even in the absence of direct bribery, other kinds of transactions involving the people's representatives have the potential to overwhelm the electoral connection, especially legalized lobbying relationships (McMenamin, 2012).

Programmatically, pre-empting this spoiler condition seems to depend on structures of public law related to informal corruption, directing our attention toward judicial processes in particular. Specialized judicial investigation of cases of informal corruption, however, must be recognized as an alternative (or, at best, a supplement) to another, purely electoral option (already discussed above): putting mass media in the role of investigators and mass electorates in the role of juries. But the efficacy of institutional solutions here may be inherently limited by other factors. Comparative analysis suggests that legal political donations by business interests can sustain personal relationships with decision-makers in some types of economies but not others: yes, in "liberal" Canada and Australia; no, in "co-ordinated" Germany (McMenamin, 2012). Deep economic structures may therefore matter more than intermediate institutions in this respect.

\section{C-6. Unequal Campaign Funding}

Financial inequality can also lead, at least in states where campaigns are funded by private donors, to a more formal, legalized inequality of influence over elected officers. This is one of several respects in which the procedural environment in which elections take place can effect elite rather than popular control of public affairs. Because campaign-related institutions also impact conditions of public information and discourse, they deserve separate treatment from the problem of informal pecuniary corruption.

Methodologically, a focus on roll-call positiontaking (e.g. Gailmard \& Jenkins, 2009) has been used to determine whether votes follow dollars, with generally negative results. But this approach systematically understates the influence of economic interests on policy because many important benefits are actually distributed in less visible (and less easily quantified) ways, e.g. legislative amendments and regulatory directives (Fellowes \& Wolf, 2004). More incisive analytics tend to give more cause for concern. One attempt to analyze campaign funding in terms of an "investment theory" of American electoral politics has found evidence that parties and candidates switch policies after elections in response to the interests of campaign donors (Ferguson, 1995): the deterrent power of votes, in other words, can be matched by that of dollars. It also makes strategic sense for elected officers to anticipate the reactions to their policies of not only their own donors but also their opponents' (Ball, 1999): the threat of a future donation to one's opponent may be as effective 
as a past donation to oneself. This is a kind of electoral accountability, but with sanctioning power held by moneyed elites more than enfranchised citizens.

Programmatically, various legal regulations of the campaign process may affect the susceptibility of elected officers to incentives provided by campaign donations. Schemes of private financing and paid publicity should be expected to diminish the relative power of votes compared to dollars. This expectation accords with the baseline assumption that public financing and free publicity are intermediate conditions of electoral accountability.

A key theoretic issue in this connection involves levels of electoral competition. Financial regulations may bear on how competitive races are, and competitiveness may be a necessary condition of electoral accountability. The classic assumption is that a high level of competitiveness is needed to pose a credible deterrent against incumbents' bad behavior (i.e. the risk of losing office must be tangible). Recent research suggests, moreover, that more competitive races yield informationally richer campaigns (Lipsitz, 2011), thereby aiding voter judgments about whom to reward and whom to punish. On the other hand, uncompetitive races might be taken as a sign that voters know what they want and politicians are good at giving it to them (Buchler, 2011). On balance, however, this second perspective seems less compelling because it assumes a high level of accountability in order to explain a lack of competitiveness, rather than addressing the causal prerequisites of accountability itself.

Varying levels of competitiveness have been studied across the USA's multiple electoral jurisdictions. The difficulty of challengers in gathering funds against an entrenched incumbent, for instance, has been identified as one of the principal causes of the decline in competitive elections for Congress (Abramowitz, Alexander, \& Gunning, 2006b). The weakness of state-level campaign-funding regulations designed to reduce funding inequalities has been found to play a similarly anticompetitive role in sub-national elections (Hamm \& Hogan, 2008; Hogan, 2004). If high levels of information and competition in election campaigns promote electoral accountability, institutions that permit or encourage funding inequalities presumably constitute a spoiler condition.

\section{C-7. Weak Parties}

Variations in partisan institutions can have an enormous impact on electoral dynamics, and political scientists have long felt that strong parties are essential to collective accountability (e.g. Carey, 2009). Strong parties could in theory supply coherent ideological cues to compensate for voters' limited information, yet the failure of parties actually to play this role in various contexts has often been lamented. One of the signal cases of such lamentation, at the conclusion of an otherwise sanguine account of the analytic possibilities of "retrospective voting," held that "collective responsibility has leaked out of the system" as a result of American parties' lack of organizational and ideological coherence (Fiorina, 1981, pp. 202-210). A similar problem arises where a lack of partisan unity obscures "clarity of responsibility" for policy (Powell, 2000, chapter 3) or fails to offer viable electoral alternatives, which are essential to make ballots count as sanctions (Anderson, 2007, pp. 281-286). If elected, structurally weak parties may be unable to carry out a policy program that is responsive to those voters who deliberately deposed the incumbents.

Programmatically, though a country's party system as a whole may implicate the grand level of constitutional structure, weak political parties could be combatted at the intermediate level of internal procedure. Rules of candidate selection, for example, are often determined internally but may have broader effects justifying regulation through public law. Here a theoretic dilemma arises. The most internally democratic procedures, such as the direct balloting of party members to nominate candidates, may conflict with other liberal values (Hazan \& Rahat, 2010) to the extent that they render partisan organizations disorganized or undisciplined. For our purposes, however, the relevant point is analytic rather than normative: internal weakness can inhibit parties' role in electoral accountability throughout the polity as a whole. Theoretically, then, intermediate measures of public law which regulate internal procedures to promote party discipline would tend to promote electoral accountability.

\section{C-8. Strong Parties}

If political parties may endanger accountability when they are too weak internally, they are also a threat when too strong externally. For example, in the absence of a national electoral administration in the USA (Lehoucq, 2002, pp. 40-43), state-level party organizations have historically set the rules of the electoral game, thereby shaping the conditions under which their members are supposed to be subject to electoral control (and at all levels of government, local and national alike). In most American states, the two major parties face lower barriers to ballot access than others but may nonetheless exclude non-members from nominating-primary elections. As a result, American primaries tend to be steered by a relatively small minority of ideological extremists (Jacobs \& Shapiro, 2000, pp. 3236; Lee, Moretti, \& Butler, 2004; Masket \& Noel, 2012). Partisan control of the boundaries of electoral districts also injects party-elite judgments into electoral results at an early stage of the electoral process in the USA (Thompson, 2004, pp. 52-55). The steady decline in the number of competitive or "marginal" districts for the 
House of Representatives in recent decades is an undisputed trend, though the causal agency of partisan redistricting is hotly debated (see Abramowitz et al., 2006a; McDonald, 2006).

Theoretically, the danger to electoral accountability comes not from all kinds of partisan strength but specifically from control over core electoral institutions. It has been understood since the early principal-agent models that electoral results could be said to reflect elite more than popular judgments as parties become strong enough to control the basic procedures by which governments are supposed to be held accountable. The drawing of "safe" partisan districts, in particular, may be the USA's peculiar contribution toward minority rule. If a small number of strong partisans can oust an incumbent in a nominating primary that excludes non-members, but a much larger number of voters cannot do the same at the general election because the district as a whole is uncompetitive, the principal to whom the incumbent is truly accountable is the smaller faction, not the larger. Beyond the USA, broader trends in partisan organization (which have fallen under the rubric of the "cartel party" thesis) indicate that major parties around the world are increasingly able to sustain their positions through state support, to place control of electoral processes in the hands of partisan legislators, and to engage in collusive behavior with one another within any given party system (Katz \& Mair, 2009). Such trends violate the openness and competitiveness that are assumed to be necessary for votes to act as effective sanctions.

Programmatically, non-partisan districting can weaken parties in the sense in which strength would tend to crush electoral accountability. In the US states, independent districting commissions (such as are used at the national level in other countries) have been found to lead to more competitive races (Cottrill, 2012). Higher levels of electoral competition, in turn, can have a variety of pro-accountability effects, including a richer informational environment for voters during the campaign season (Lipsitz, 2011).

With respect to candidate selection, however, the crucial theoretic insight is that appropriate institutional reforms depend very much on the broader partisan context. In light of the value of internal party discipline (see C-7 above), measures of public law should at the same time aspire to weaken parties externally so that dissenting party members have real exit options (i.e. access to other viable parties). In an entrenched partisan duopoly, however, the lack of viable exit options would require that parties also be weakened internally in the sense that public law should force them to nominate their candidates through open primaries. These are intermediate institutional fixes that may be more readily available than other, more comprehensive measures, such as the creation of multi-member districts or proportional voting schemes.

\section{D-9. Electoral Fraud}

The fourth crucial condition (D), relating to voters' norms, is bound to implicate cultural and behavioral variables outside the institutional focus of my analysis. Yet some procedural structures do crucially impinge on our ability to interpret voting as an act with sanctioning power. Most democrats intuitively sense that an accurate count of votes is the sine qua non of interpreting the outcome as a popular reward or a popular punishment; otherwise the voters' will does not fully determine the outcome. Factors promoting inaccurate tallies therefore become relevant to the question of electoral accountability.

The ease and variety of methods of manipulating electoral results in mass elections involving thousands or millions of voters are often under-estimated or assumed away. There are, first of all, "pre-election tools" (Donno \& Roussias, 2012) that are designed to intimidate and to discourage electoral competition. Fraud properly speaking then comes in the form of classic strategies such as registering fictitious, deceased, or otherwise ineligible voters; using "repeaters" to vote more than once; imprisoning eligible voters and releasing them after the polls are closed; physically blocking eligible voters from leaving home or entering a polling station; administratively purging eligibile voters from voting lists; bribing or intimidating eligible voters before they cast their ballots; and tampering with ballots or otherwise miscounting them after they are cast. Though the academic literature on electoral fraud is relatively thin (Lehoucq, 2003, pp. 236-237), these techniques have been amply attested for the nineteenth-century USA (Argersinger, 1985), nineteenthcentury Spain (Darde, 1996), and the twentieth-century USA (Campbell, 2005), for example. Recent cases of fraud have attracted attention in Russia and Ukraine (Myagkov, Ordeshook, \& Shakin, 2009) as well as Great Britain, Mexico, Germany, Taiwan, Spain, and Argentina (Lehoucq, 2003, pp. 237-245). Of course the 2000 presidential vote in the American state of Florida famously failed to meet basic international standards of "free and fair" elections such that fraud could be ruled out (Bjornlund, 2004, pp. 3-6).

Methodologically, electoral fraud may affect not only political careers but also academic ones. Political scientists, especially those reliant on vote-share as a key variable, routinely assume the accuracy of official electoral results. In so far as reliable counts are essential to interpreting the popular will behind the voting, the reality of fraud should be taken seriously in electoral studies.

Programmatically, schemes of election monitoring, both formal (e.g. international teams of monitors) and informal (e.g. domestic journalists and party activists), may help to promote clean elections. Domestically, a centralized and professionalized electoral administra- 
tion is taken for granted as a prerequisite in some but not all democracies. Research on Latin America, for example, has found that a non-partisan, professional electoral administration at the national level is virtually a sufficient condition of clean elections (Hartlyn, McCoy, \& Mustillo, 2008); in contexts with relatively low levels of fear and polarization, an electoral commission staffed according to balanced partisan representation may also do the trick.

\section{D-10. Electoral Inaccuracy}

Contrary to popular belief, basic facts of life mean that there are no definitive technical solutions to the problem of inaccurate electoral results-whether intentionally inaccurate (via fraud) or unintentionally so. Studies of elections in the United States suggest that voter error in any given election accounts for $1.5 \%$ to $2.5 \%$ of the total vote (Stewart, 2010, p. 372). It is well known that certain types of ballot yield lower rates of voter error than others, e.g. optical-scan (less) vs. punch-card ballots (more) (Saltman, 2006, p. 189). Techniques for counting ballots are as important as for marking them. Computer technology, for instance, can reduce marking errors (Herrnson et al., 2008, chapter 4) but may not offer counting procedures that are secure from fraudulent activity (pp. 111-112). As long ago as the early 1970's, when computers were first used to tabulate results from elections in southern California, a team of computer scientists demonstrated that the voting results could be systematically skewed by technical manipulation (Saltman, 2006, pp. 166-167); the trick has been repeated with computerized "touchscreen" voting machines in recent years (pp. 201-204). There is a catch-22 within touch-screen technology, which promises relatively low error rates but also relatively little possibility of public verification (Stewart, 2010, pp. 359, 364, 367-368): attempts to make computerized voting machines generate auditable papertrails have had the side-effect of increasing voter error (Herrnson et al., 2008, chapter 6).

Theoretically, political scientists should consider the concept of recountability, or the capacity of electoral machinery to have its results publicly verified or checked, as an essential operational component of electoral accountability. Reformed administrative practices cannot solve the basic problem that computerprocessed results are not amenable to a genuine recount: as electoral technology becomes more sophisticated, the number of persons capable of certifying the results (i.e. qualified software engineers) shrinks. Unlike a twelve-member jury or a 500-member assembly, a mass electorate makes a publicly verifiable count very slow and very costly to conduct. But even a slow and costly recount is better than no recount at all, if electoral accountability truly depends on accurate vote-tallies.
Programmatically, the agenda for intermediate institutional remedies should be to use administrative and legislative measures to ensure the use of appropriate voting technology. If recountability is taken to be a sine qua non of electoral fairness and accuracy, the current state of research suggests that paper ballots designed to be read by optical-scan machines offer a reasonable balance between relatively low error rates and relatively easy recounts.

\section{Conclusion}

Synthesizing theoretical and empirical research on electoral accountability reveals that some democracies' institutions endow them with greater capacity to channel popular power through the electoral process than others. It is clear, in particular, that democracies with publicly owned media, adequate compensation for representatives, public financing of campaigns, free-ofcharge campaign broadcasts, closely monitored elections, and recountable voting technology offer a significantly greater chance for voters to hold governments accountable than do democracies without these resources. This difference is theoretical in nature: a wellfounded, analytically coherent expectation about institutional effects on the all-important (and hard to operationalize) value of popular power.

The theoretical picture is less clear for other kinds of institutions than those just mentioned, but my reinterpretation of the principal-agent approach to electoral accountability nonetheless supplies sound assumptions to guide future research. Problems of voter judgment may have no solution at all, or no institutional solution, but theories of and experiments with deliberative assemblies are laudable efforts to investigate that question. Clarity of responsibility may be all but unachievable outside jurisdictions that are governed by a unicameral parliament, barring major constitutional upheaval. Judicial monitoring of informal corruption may be motivated by voter ignorance or inattention, but it also keeps citizens dependent on the good will of judicial elites themselves. The analytical point here is that relying on institutionalized popular power is different from depending on the democratic benevolence of elite agents.

Perhaps the most complex aspect of electoral accountability involves parties and party systems, since different contexts demand different (even opposite) institutional remedies. In multi-party systems with plentiful options for voters and activists, internal party discipline is essential and should be promoted by, for example, closed mechanisms of candidate selection. In less fluid party systems, in which electoral viability and actual legislative representation are precious resources reserved only for two or three parties, internal governance should be opened up as much as possible, especially for non-members. The up-shot is that electoral 
accountability requires "open primaries" in the USA but closed processes in multi-party democracies.

The "top ten" list of spoiler conditions does present a daunting challenge for the idea of elections as vehicles of popular power, but it also offers guidance for meeting the challenge. Nonetheless, some may believe that this notion should itself be abandoned in favor of a focus on new kinds of legislative structure selected by non-electoral means. Or, easier still, hope for strong accountability could give way to a chastened, "minimalist" vision of electoral democracy: a modest project with a decent track-record of installing liberal and mild elites over a quarrelsome yet largely peaceable populace. This model may indeed describe actual Western democracies better than does the old-fashioned, rhetorically spirited account of the modern constitutional republic as a form of popular self-government. It is also possible that the insurgent citizens who have been clamoring for political control over their own lives in recent years, whether in Egypt or Iran or Hong Kong (or Greece or Spain, for that matter), are acting in either ironic or delusional fashion. If they are not, however, the possibility of institutionalizing popular power through redesigning electoral structures is something that the cause of civil peace cannot do without.

\section{Acknowledgments}

My thanks are due to Fabrice Lehoucq for his comments on a previous version of this paper, to many other colleagues who have responded to my public presentations of various papers on the topic of electoral accountability over the years, and to Josh Little and Spencer Mitchell for research assistance.

\section{Conflict of Interests}

The author declares no conflict of interests.

\section{References}

Abramowitz, A. I., Alexander, B., \& Gunning, M. (2006a). Don't blame redistricting for uncompetitive elections. PS: Political Science and Politics, 39, 87-90.

Abramowitz, A. I., Alexander, B., \& Gunning, M. (2006b). Incumbency, redistricting, and the decline of competition in U.S. house elections. Journal of Politics, 68, 75-88.

Alcaniz, I., \& Hellwig, T. (2011). Who's to blame? The distribution of responsibility in developing democracies. British Journal of Political Science, 41, 389-411.

Anderson, C. D. (2006). Economic voting and multilevel governance: A comparative individual-level analysis. American Journal of Political Science, 50, 449463.

Anderson, C. J. (2007). The end of economic voting?
Contingency dilemmas and the limits of accountability. Annual Review of Political Science, 10, 27196.

Anderson, C. J., Blais, A., Bowler, S., Donovan, T., \& Listhaug, O. (2005). Losers' consent: Elections and democratic legitimacy. Oxford, UK: Oxford University Press.

Argersinger, P. H. (1985). New perspectives on election fraud in the gilded age. Political Science Quarterly, 100, 669-87.

Arnold, R. D. (2004). Congress, the press, and political accountability. Princeton, NJ: Princeton University Press.

Ashworth, S. (2012). Electoral accountability: Recent theoretical and empirical work. Annual Review of Political Science, 15, 183-201.

Bachner, J., \& Ginsberg, B. (2014). What the government thinks of the people. Paper presented at the American Political Science Association, Washington, DC.

Ball, R. (1999). Opposition backlash and platform convergence in a spatial voting model with campaign contributions. Public Choice, 98, 269-286.

Barro, R. (1973). The control of politicians: An economic model. Public Choice, 14, 19-42.

Berry, C. R., \& Howell, W. G. (2007). Accountability and local elections: Rethinking retrospective voting. Journal of Politics, 69, 844-858.

Besley, T. (2006). Principled agents? The political economy of good government. New York, NY: Oxford University Press.

Bjornlund, E. (2004). Beyond free and fair. Baltimore, MD: Johns Hopkins University Press.

Brown, A. R. (2010). Are governors responsible for the state economy? Partisanship, blame, and divided federalism. Journal of Politics, 73, 605-615.

Buchler, J. (2011). Hiring and firing public officials: Rethinking the purpose of elections. New York, NY: Oxford University Press.

Bullock, J. G. (2011). Elite influence on public opinion in an informed electorate. American Political Science Review, 105, 496-515.

Callenbach, E., \& Phillips, M. (2008). A citizen legislature. Exeter, UK: Imprint Academic.

Campbell, T. (2005). Deliver the vote: A history of election fraud, an American political tradition, 17422004. New York, NY: Avalon.

Carey, J. M. (2009). Legislative voting and accountability. New York, NY: Cambridge University Press.

Chang, E. C. C., Golden, M. A., \& Hill, S. J. (2010). Legislative malfeasance and political accountability. World Politics, 62, 177-220.

Claassen, R. L., \& Highton, B. (2006). Does policy debate reduce information effects in public opinion? Analyzing the evolution of public opinion on health care. Journal of Politics, 68, 410-420.

Cottrill, J. B. (2012). The effects of non-legislative ap- 
proaches to redistricting on competition in congressional elections. Polity, 44, 32-50.

Cox, G. W., \& Katz, J. N. (2002). Elbridge Gerry's salamander: The electoral consequences of the reapportionment revolution. New York, NY: Cambridge University Press.

Darde, C. (1996). Fraud and the passivity of the electorate in Spain, 1875-1923. In E. Posada-Carbo (Ed.), Elections before democracy: The electoral history of Europe and Latin America. London: Macmillan.

Donno, D., \& Roussias, N. (2012). Does cheating pay? The effect of electoral misconduct on party systems. Comparative Political Studies, 45, 575-605.

Dunn, J. (1999). Situating democratic political accountability. In A. Przeworski, S. C. Stokes, \& B. Manin (Eds.), Democracy, accountability, and representation. New York, NY: Cambridge University Press.

Eskridge, W. N. (2008). Vetogates, Chevron, preEmption. Notre Dame Law Review, 83, 1441-1494.

Fellowes, M. C., \& Wolf, P. J. (2004). Funding mechanisms and policy instruments: How business campaign contributions influence congressional votes. Political Research Quarterly, 57, 315-324.

Ferejohn, J. (1986). Incumbent performance and electoral control. Public Choice, 50, 5-25.

Ferejohn, J. (1999). Accountability and authority: Toward a theory of political accountability. In A. Przeworski, S. C. Stokes, \& B. Manin (Eds.), Democracy, accountability, and representation. New York, NY: Cambridge University Press.

Ferguson, T. (1995). The golden rule: The investment theory of party competition and the logic of moneydriven political systems. Chicago, IL: University of Chicago Press.

Fiorina, M. P. (1981). Retrospective voting in American national elections. New Haven, CT: Yale University Press.

Gailmard, S., \& Jenkins, J. A. (2009). Agency problems and electoral institutions: The seventeenth amendment and representation in the senate. American Journal of Political Science, 53, 324-342.

Gastil, J., Deess, E. P., Weiser, P. J., \& Simmons, C. (2010). The jury and democracy: How jury deliberation promotes civic engagement and political participation. New York, NY: Oxford University Press.

Gelineau, F., \& Remmer, K. L. (2005). Political decentralization and electoral accountability: The Argentine experience, 1983-2001. British Journal of Political Science, 36, 133-157.

Hamm, K. E., \& Hogan, R. E. (2008). Campaign-finance laws and candidacy decisions in state legislative elections. Political Research Quarterly, 61, 458-467.

Hardin, R. (2000). Democratic epistemology and accountability. Social Philosophy and Policy, 17, 110126.

Hartlyn, J., McCoy, J., \& Mustillo, T. M. (2008). Electoral governance matters: Explaining the quality of elec- tions in contemporary Latin America. Comparative Political Studies, 41, 73-98.

Hazan, R. Y., \& Rahat, G. (2010). Democracy within parties: Candidate selection methods and their political consequences. New York, NY: Oxford University Press.

Hellwig, T., \& Samuels, D. (2008). Electoral accountability and the variety of democratic regimes. British Journal of Political Science, 38, 65-90.

Herrnson, P. S., Niemi, R. G., Hanmer, M. J., Bederson, B. B., Conrad, F. C., \& Traugott, M. W. (2008). Voting technology: The not so simple act of casting a ballot. Washington, DC: Brookings Institution.

Hogan, R. E. (2004). Challenger emergence, incumbent success, and electoral accountability in state legislative elections. Journal of Politics, 66, 1283-1303.

Huber, G. A., Hill, S. J., \& Lenz, G. S. (2012). Sources of bias in retrospective decision-making: Experimental evidence on voters' limitations in controlling incumbents. American Political Science Review, 106, 720-741.

Jacobs, L. R., \& Shapiro, R. Y. (2000). Politicians don't pander: Political manipulation and the loss of democratic responsiveness. Chicago, IL: University of Chicago Press.

Jones, P. E. (2011). Accountability for policy positions and policy outcomes in congress. Journal of Politics, 73, 764-782.

Katz, R. S., \& Mair, P. (2009). The cartel party thesis: A restatement. Perspectives on Politics, 7, 753-766.

Key, V. O. (1966). The responsible electorate: Rationality in presidential voting, 1936-60. Cambridge, MA: Harvard University Press.

Kull, S., Ramsay, C., \& Lewis, E. (2004). Misperceptions, the media, and the Iraq war. Political Science Quarterly, 118, 569-598.

Lee, D. S., Moretti, E., \& Butler, M. J. (2004). Do voters affect or elect policies? Evidence from the U.S. house. Quarterly Journal of Economics, 119, 807859.

Lehoucq, F. (2002). Can parties police themselves? Electoral governance and democratization. International Political Science Review, 23, 29-46.

Lehoucq, F. (2003). Electoral fraud: Cases, types, and consequences. Annual Review of Political Science, 6, 233-256.

Leib, E. J. (2004). Deliberative democracy in America: $A$ proposal for a popular branch of government. University Park, PA: Pennsylvania State University Press.

Leon, S. (2011). Who is responsible for what? Clarity of responsibilities in multilevel states. European Journal of Political Research, 50, 80-109.

Lipsitz, K. (2011). Competitive elections and the American voter. Philadelphia, PA: University of Pennsylvania Press.

Maloy, J. S. (2008). The colonial American origins of 
modern democratic thought. New York, NY: Cambridge University Press.

Maloy, J. S. (2014). Linkages of electoral accountability: Empirical results and methodological lessons. Politics and Governance, 2(2), 13-27.

Manin, B., Przeworski, A., \& Stokes, S. C. (1999). Elections and representation. In A. Przeworski, S. C. Stokes, \& B. Manin (Eds.), Democracy, accountability, and representation. New York, NY: Cambridge University Press.

Maravall, J. M. (1999). Accountability and manipulation. In A. Przeworski, S. C. Stokes, \& B. Manin (Eds.), Democracy, accountability, and representation. New York, NY: Cambridge University Press.

Maravall, J. M. (2010). Accountability in coalition governments. Annual Review of Political Science, 13, 81-100.

Masket, S. E., \& Noel, H. (2012). Serving two masters: Using referenda to assess partisan versus dyadic legislative representation. Political Research Quarterly, 65, 104-123.

McCormick, J. P. (2011). Machiavellian democracy. New York, NY: Cambridge University Press.

McDonald, M. P. (2006). Drawing the line on district competition. PS: Political Science and Politics, 39, 91-94.

McMenamin, I. (2012). If money talks, what does it say? Varieties of capitalism and business financing of parties. World Politics, 64, 1-38.

McMillan, J., \& Zoido, P. (2004). How to subvert democracy: Montesinos in Peru. Journal of Economic Perspectives, 18(4), 69-92.

Myagkov, M., Ordeshook, P. C., \& Shakin, D. (2009). The forensics of election fraud: Russia and Ukraine. Cambridge, UK: Cambridge University Press.

O'Donnell, G. (2003). Horizontal accountability: The legal institutionalization of mistrust. In S. Mainwaring \& C. Welna (Eds.), Democratic accountability in Latin America. Oxford, UK: Oxford University Press.

Paine, T. (2003). Common sense, rights of man, and other essential writings. New York, NY: Signet Classics.

Pereira, C., Melo, M. A., \& Figueiredo, C. M. (2009). The corruption-enhancing role of re-election incentives? Counter-intuitive evidence from Brazil's audit re- ports. Political Research Quarterly, 62, 731-744.

Powell, G. B., \& Whitten, G. D. (1993). A cross-national analysis of economic voting. American Journal of Political Science, 37, 391-414.

Powell, G. B. (2000). Elections as instruments of democracy: Majoritarian and proportional visions. New Haven, CT: Yale University Press.

Przeworski, A. (1999). Minimalist theory of democracy: A defence. In I. Shapiro \& C. Hacker-Cordon (Eds.), Democracy's value. New York, NY: Cambridge University Press.

Prior, M. (2007). Post-broadcast democracy: How media choice increases inequality in political involvement and polarizes elections. New York, NY: Cambridge University Press.

Przeworski, A., Stokes, S. C., \& Manin, B. (1999). Democracy, accountability, and representation. New York, NY: Cambridge University Press.

Saltman, R. G. (2006). The history and politics of voting technology. New York, NY: Palgrave Macmillan.

Snyder, J. M., \& Stromberg, D. (2010). Press coverage and political accountability. Journal of Political Economy, 118, 355-408.

Stewart, C. (2010). Voting technologies. Annual Review of Political Science, 14, 353-378.

Sutherland, K. (2008). A people's parliament: A (revised) blueprint for a very English revolution. Exeter, UK: Imprint Academic.

Thompson, D. F. (2004). Election time: Normative implications of temporal properties of the electoral process in the United States. American Political Science Review, 98, 51-64.

Tsai, L. L. (2007). Accountability without democracy: Solidary groups and public goods provision in rural China. Cambridge, UK: Cambridge University Press.

Tsebelis, G. (2002). Veto players: How political institutions work. Princeton, NJ: Princeton University Press.

Wolpert, R. M., \& Gimpel, J. G. (1997). Information, recall, and accountability: The electorate's response to the Clarence Thomas nomination. Legislative Studies Quarterly, 22, 535-550.

Zakaras, A. (2010). Lot and democratic representation: A modest proposal. Constellations, 17, 455-471.

\section{About the Author}

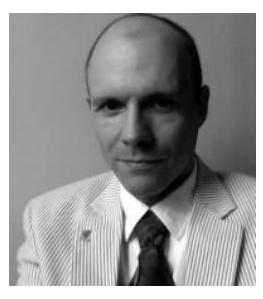

\section{Dr. J. S. Maloy}

J. S. Maloy is Professor and Kaliste Saloom Endowed Chair in Political Science at the University of Louisiana, Lafayette. He is the author of two books with Cambridge University Press, most recently Democratic Statecraft: Political Realism and Popular Power (2013). He has also published articles on a variety of topics related to the theoretical and empirical study of democracy, in venues such as Journal of Peace Research, Journal of Politics, American Journal of Political Science, and Canadian Journal of Political Science. 